\title{
Extracellular expression of a novel $\beta$-agarase from Microbulbifer sp. Q7, isolated from the gut of sea cucumber
}

\author{
Qian Su, Tianyi Jin, Yuan Yu, Min Yang, Haijin Mou ${ }^{*}$ and Li Li
}

\begin{abstract}
A novel endo-type $\beta$-agarase was cloned from an agar-degrading bacterium, Microbulbifer sp. Q7 (CGMCC No. 14061), that was isolated from sea cucumber gut. The agarase-encoding gene, ID2563, consisted of $1800 \mathrm{bp}$ that encoded a 599-residue protein with a signal peptide of 19 amino acids. Sequence analysis suggested that the agarase belongs to the $\mathrm{GH} 16$ family. The agarase was expressed in Escherichia coli with a total activity of $4.99 \mathrm{U} / \mathrm{mL}$ in fermentation medium. The extracellular enzyme activity accounted for $65.73 \%$ of the total activity, which indicated that the agarase can be extracellularly secreted using the wild-type signal peptide from Microbulbifer sp. Q7. The agarase exhibited maximal activity at approximately $40^{\circ} \mathrm{C}$ and $\mathrm{pH}$ 6.0. It was stable between $\mathrm{pH} 6.0$ and $\mathrm{pH} 9.0$, which was a much wider range than most of the reported agarases. The agarase was sensitive to some metal ions $\left(\mathrm{Cu}^{2+}, \mathrm{Zn}^{2+}\right.$ and Fe $\left.{ }^{3+}\right)$, but was resistant to urea and SDS. The agarase hydrolyzed $\beta-1,4-$ glycosidic linkages of agarose, primarily yielding neoagarotetraose and neoagarohexaose as the final products. These indicate that this recombinant agarase can be an effective tool for the preparing functional neoagaro-oligosaccharides.
\end{abstract}

Keywords: $\beta$-Agarase, Microbulbifer sp. Q7, Extracellular expression, Neoagaro-oligosaccharides

\section{Introduction}

Agarose consists of alternating 3-O-linked $\beta$-D-galactose and 4-O-linked 3,6-anhydro- $\alpha$-L-galactose units (Duckworth and Yaphe 1971). Oligosaccharides prepared from agarose exhibit various biological and physiological functions, such as antioxidant (Wang et al. 2004), and antiinflammatory activities (Yun et al. 2013), moisturizing and whitening effects on melanoma cells (Kobayashi et al. 1997), inhibition of bacterial growth, and inhibition of starch degradation (Giordano et al. 2006). Owing to these properties of agar-oligosaccharides, their preparation and potential applications have attracted widespread attention.

Enzymatic hydrolysis is one of the most widely used methods for the preparation of agar-oligosaccharides owing to its high specificity and efficiency. Agarases are a group of glycoside hydrolases $(\mathrm{GH})$, which includes

*Correspondence: mousun@ouc.edu.cn; Ilcs0229@163.com College of Food Science and Engineering, Ocean University of China, Qingdao 266003, Shandong, China $\alpha$-agarases (EC 3.2.1.158) and $\beta$-agarases (EC 3.2.1.81). These enzymes cleave $\alpha-1$, 3-linkages of agarose to produce agaro-oligosaccharides (Potin et al. 1993) and inter- $\beta$-1,4-linkages to produce neoagaro-oligosaccharides (Kirimura et al. 1999), respectively. Some agarases, mostly belonging to $\beta$-agarase, have been isolated and cloned from different microorganisms, such as Vibrio sp. AP-2 (Aoki et al. 1990), Alteromonas sp. E-1 (Kirimura et al. 1999), Bacillus sp. MK03 (Suzuki et al. 2003), Zobellia galactanivorans Dsij (Allouch et al. 2003), the archaea Halococcus sp. 197A (Minegishi et al. 2013), Thalassospira profundimonas sp. fst-13007 (Zeng et al. 2016), Gayadomonas joobiniege sp. G7 (Jung et al. 2017) and Aquimarina agarilytica sp. ZC1 (Lin et al. 2017).

Sea cucumbers are deep-sea echinoderms that feed on seaweed and plankton. Thus, we hypothesized that their guts contain bacterial strains that degrade seaweed polysaccharides. In our previous work, we isolated a strain, Microbulbifer sp. Q7, from sea cucumber gut that was able to degrade agar and alginate. The whole genome of Microbulbifer sp. Q7 was sequenced and the agarase gene 
was identified (Yang et al. 2017). Herein, we describe the heterologous expression of agarase in E. coli. To increase extracellular secretion of the agarase, the wild-type signal peptide from Microbulbifer sp. Q7 was used. Its enzymatic activity and hydrolytic products of the agarase were also studied.

\section{Materials and methods}

\section{Strains, plasmids and media}

Microbulbifer sp. Q7 (CGMCC no. 14061) was isolated from the guts of sea cucumbers and cultured in 2216E medium, the whole genome of Q7 was sequenced using a HiSeq PE150 (Novogene Bioinformatics Technology Co. Ltd., China) (Yang et al. 2017). The E. coli DH5 $\alpha$ were used for cloning, and the E. coli BL21(DE3) were used for protein expression. Both strain were cultured in LuriaBertani (LB) medium containing $100 \mu \mathrm{g} / \mathrm{mL}$ ampicillin. The pProEX-HTa vector (Yellow Sea Fisheries Research Institute, Chinese Academy of Fishery Science) was used as the cloning and expression vector.

\section{Sequence analysis of the ID2563 gene}

Our previous work sequenced the Microbulbifer sp. Q7 genome and identified the agarase gene, ID2563 (Yang et al. 2017). The ID2563 sequence was deposited into NCBI under the Accession Number WP_066965750.1.DNAMAN software was used to analyze the sequence of the gene. The signalP 4.1 server (http://www.cbs.dtu.dk/services/SignalP/) was used to predict the signal peptide sequence of ID2563. Analysis of its physicochemical properties was performed using ProtParam (http://web.expasy.org/protparam/). The conserved domain and catalytic site were predicted by the Conserved Domain Database (https://www.ncbi.nlm.nih. gov/cdd/). Mega5.0 was used to construct a phylogenetic tree using the neighbor-joining method.

\section{Cloning and expression of the recombinant agarase} Genomic DNA from Microbulbifer sp. Q7, was extracted using a total DNA extraction kit (Sangon, Shanghai China). For extracellular agarase expression, the ID2563 gene with its original signal sequence was amplified by using the following primers, ID2563-F (CGGGATCCATGAAAACCACTCAGGGCG, BamHI site underlined) and ID2563-R (CCCAAGCTTTTAATTACTTAGCACGAACTTATCC, HindIII site underlined). The amplicon was cloned into pProEX-HTa. The recombinant plasmid was transformed into E. coli $\mathrm{DH} 5 \alpha$ and plated on LB supplemented with $100 \mu \mathrm{g} / \mathrm{mL}$ ampicillin. Successful cloning of ID2563 into pProEX-HTa was confirmed by sequencing. pProEX-HTa-ID2563 was transformed into E. coli BL21 (DE3) and plated on LB supplemented with $100 \mu \mathrm{g} / \mathrm{mL}$ ampicillin. For agarase expression, the $E$. coli
BL21(DE3) containing pProEX-HTa-ID2563 were grown at $37^{\circ} \mathrm{C}$ in LB medium supplemented with $100 \mu \mathrm{g} / \mathrm{mL}$ ampicillin. When the $\mathrm{OD}_{600}$ reached 0.6-0.8, isopropyl$\beta$-thiogalactoside (IPTG) was added to a final concentration of $1 \mathrm{mM}$. Cell were incubated at $23^{\circ} \mathrm{C} 160 \mathrm{rpm}$ for $24 \mathrm{~h}$.

\section{Assay of enzyme activity}

Agarase activity was determined using the 3,5-dinitrosalicylic acid (DNS) method (Miller 1959). Briefly, $100 \mu \mathrm{L}$ of enzyme was added to $900 \mu \mathrm{L}$ of $20 \mathrm{mM}$ Tris- $\mathrm{HCl} \mathrm{pH}$ 7.2 containing $0.2 \%(\mathrm{w} / \mathrm{v})$ agarose, and the reaction was incubated at $40{ }^{\circ} \mathrm{C}$ for $5 \mathrm{~min}$. One milliliter of DNS reagent added, and the reaction was heated in boiling water for $5 \mathrm{~min}$ and rapidly cooled. The absorbance was measured at $520 \mathrm{~nm}$ and compared with a standard curve for D-galactose. Enzyme activity (1 U) was defined as the amount of enzyme required to liberate $1 \mu \mathrm{M}$ of D-galactose per min.

\section{Purification of recombinant agarase}

BL21(DE3) E. coli expressing his-tagged agarase were pelleted by centrifugation $(10,000 \mathrm{rpm}, 10 \mathrm{~min})$. The supernatant and pellet were used to determine extracellular and intracellular agarase activity, respectively. Pelleted cells were resuspended in phosphate buffer saline and lysed by ultrasonication. Cell debris was removed by centrifugation (12,000 rpm, $10 \mathrm{~min})$. Extracellular histagged agarase was purified using a Ni Sepharose 6FF column (GE Healthcare, USA) and imidazole concentrations between 10 and $400 \mathrm{mM}$. Fractions that were positive for agarase activity were pooled and concentrated using an ultrafiltration concentrator. Purified agarase was detected by $12 \%$ sodium dodecyl sulfate polyacrylamide gel electrophoresis (SDS-PAGE). Agarase concentration was measured using the prestained protein ladder (Thermo, range $10-180 \mathrm{kDa}$ ).

\section{Native-PAGE and zymogram analysis}

Native-PAGE of the purified recombinant agarase solution was performed on $10 \%$ gel at $4{ }^{\circ} \mathrm{C}$. Zymogram analysis gel was soaked in Tris- $\mathrm{HCl}$ buffer (50 mM, pH 7.0) for $5 \mathrm{~min}$ after the native-PAGE. Then the gel was overlaid onto a sheet of $2 \%(\mathrm{w} / \mathrm{v})$ agarose in Tris- $\mathrm{HCl}$ buffer (50 mM, pH 7.0) and incubated at $40{ }^{\circ} \mathrm{C}$ for $30 \mathrm{~min}$. To visualize agarase activity, the agarose sheet was flooded with Lugol's iodine solution. Then the gel was removed from the agarose sheet and stained with Coomassie Brilliant Blue R-250.

\section{Properties of enzyme}

Agarase activity was measured at six temperatures between 30 and $60{ }^{\circ} \mathrm{C}$ under the standard conditions to 
determine the optimum temperature for activity. The thermal stability of agarase was determined based on its enzymatic activity after pre-incubation at different temperatures.

The optimum $\mathrm{pH}$ for agarase was determined by assessing its activity at different $\mathrm{pH}$ values. Three buffers was used: $50 \mathrm{mM} \mathrm{Na}_{2} \mathrm{HPO}_{4}$-citric acid ( $\mathrm{pH} \mathrm{3.0,4.0} \mathrm{and} \mathrm{5.0),}$ $50 \mathrm{mM}$ sodium phosphate ( $\mathrm{pH} 6.0,7.0$ and 8.0$), 50 \mathrm{mM}$ Tris- $\mathrm{HCl}(\mathrm{pH} 9.0)$ and $50 \mathrm{mM} \mathrm{Na} \mathrm{CO}_{3}-\mathrm{NaOH}$ buffer (pH 10.0 and 11.0). Extracellular agarase was pre-incubation in the buffers listed above for $2 \mathrm{~h}$ at $20^{\circ} \mathrm{C}$ and activity was measured to determine $\mathrm{pH}$-dependent stability.

To determine the effects of ions and other molecules on agarase activity, the assay was performed in the presence of the following reagents: $\mathrm{Na}^{+}$and $\mathrm{Fe}^{2+}(5,20$ and $50 \mathrm{mM}), \mathrm{K}^{+}, \mathrm{Mg}^{2+}, \mathrm{Ca}^{2+}, \mathrm{Li}^{+}, \mathrm{Fe}^{3+}, \mathrm{Zn}^{2+}, \mathrm{Cu}^{2+}$, EDTA, SDS, DTT and Urea $(5 \mathrm{mM}), 0.5 \%(\mathrm{v} / \mathrm{v})$ ethylene thioglycol, $0.5 \%(\mathrm{v} / \mathrm{v})$ Tween-80 and $0.5 \%(\mathrm{v} / \mathrm{v})$ Triton- 100. Enzyme activity was measured at $42{ }^{\circ} \mathrm{C}$ and $\mathrm{pH}$ 7.0. Reactions in the absence of the additives were used as controls.

\section{Analysis of enzymatic hydrolytic products}

The appropriate concentration of agarase was incubated with $1 \%$ agarose at $37{ }^{\circ} \mathrm{C}$ for approximately $6 \mathrm{~h}$. Then solution was separated from the undegraded agarose by centrifugation. Macromolecular agarose and impurities were precipitated from the supernatant using different ratios of alcohol to supernatant (the maximum ratio is 6:1). The end products, the supernatant of the maximum ratio precipitation, were freeze-dried (FD-1A-50 vacuum freezer dryer, Xi An DP Biological Technology, China) for use in further experiments.

The molecular masses of the end products were detected by using electrospray ionization mass spectrometry (ESIMS). Agar-oligosaccharide samples were dissolved in acetonitrile/1 $\mathrm{mM} \mathrm{NH} \mathrm{N}_{4} \mathrm{HCO}_{3}(1: 1, \mathrm{v} / \mathrm{v})$ and analyzed with the micromass Q-TOF and Q-TOF ultima instruments (Waters, Manchester, UK) in negative-ion mode.

The end products were also analyzed by ${ }^{13} \mathrm{C}-\mathrm{NMR}$ (carbon-13 nuclear magnetic resonance) spectroscopy. The lyophilized powder was dissolved in $\mathrm{D}_{2} \mathrm{O}$ and spectra were recorded on an Agilent ProPulse $500 \mathrm{MHz}$ NMR system. MestRe Nova software was used to analyze the ${ }^{13} \mathrm{C}$-NMR results. Deuterated acetone was used as an internal standard.

Agarase was added to $30 \mathrm{~mL}$ of $20 \mathrm{mM}$ Tris- $\mathrm{HCl} \mathrm{pH}$ 7.2 containing $1 \%(\mathrm{w} / \mathrm{v})$ agarose. The reaction were incubated at $40{ }^{\circ} \mathrm{C}$ for $0-5 \mathrm{~h}$ and quenched by boiling for $5 \mathrm{~min}$ to denature the agarase. Subsequently, the reaction products were applied to a thin layer chromatography (TLC) silica gel 60 F254 plate (Merck, Darmstadt, Germany) using a solution of $n$-butyl alcohol/acetic acid/ distilled water $(2: 1: 1, \mathrm{v} / \mathrm{v} / \mathrm{v})$ as the mobile phase. The plate was sprayed with $10 \% \mathrm{H}_{2} \mathrm{SO}_{4}$ in alcohol and heated to $110{ }^{\circ} \mathrm{C}$ for $10 \mathrm{~min}$ to visualize the product spots. To determine the composition of the final oligosaccharide products, the first two spots on the TLC plate were removed. Spots were dissolved in a small volume of distilled water and analyzed by ESI-MS (Agilent Technologies 6460 Triple Quad LC/MS) to determine their molecular weights.

\section{Results}

\section{Sequence analyses of the ID2563 gene}

A single open-reading frame composed of $1800 \mathrm{bp}$ was obtained directly from the genomic DNA of Microbulbifer sp. Q7. The anticipated protein product of the ID2563 gene comprised 599 amino acids and contained an $\mathrm{N}$-terminal signal peptide that was 19 residues in length $\left(\mathrm{M}_{1}-\mathrm{K}_{2}-\mathrm{T}_{3}-\mathrm{T}_{4}-\mathrm{Q}_{5}-\mathrm{G}_{6}-\mathrm{A}_{7}-\mathrm{L}_{8}-\mathrm{A}_{9}-\mathrm{A}_{10}-\mathrm{L}_{11}\right.$ $\left.\mathrm{V}_{12}-\mathrm{F}_{13}-\mathrm{S}_{14}-\mathrm{T}_{15}-\mathrm{P}_{16}-\mathrm{L}_{17}-\mathrm{M}_{18}-\mathrm{A}_{19}\right)$. The SignalP 4.1 server suggested the cleavage site of the signal peptide was likely between $\mathrm{Ala}_{19}$ and $\mathrm{Ala}_{20}$. Based on the agarase sequence, a molecular mass $(\mathrm{Mw})$ of $64.6 \mathrm{kDa}$ and an isoelectric point of 4.47 were calculated using ProtParam. The NCBI's Conserved Domain Database, classified the agarase protein as belonging to the GH16 family. Eleven active sites residues $\left(\mathrm{N}_{69}-\mathrm{W}_{71}-\mathrm{W}_{137}-\mathrm{S}_{143}-\mathrm{E}_{146}-\mathrm{D}_{148}-\mathrm{E}_{151}-\mathrm{F}_{174}-\mathrm{R}_{176}-\mathrm{E}_{256}-\mathrm{Q}_{258}\right)$ and three catalytic sites residues $\left(\mathrm{E}_{146}-\mathrm{D}_{148}-\mathrm{E}_{151}\right)$ were found within 545 aa. Protein BLAST of the amino acid sequence showed that the protein shared 85\% homology with the agarase from Microbulbifer agarilyticus (GenBank Accession No. BAE06228.1). There were few similarities with the agarase sequences of Coraliomargarita akajimensis (WP _013042114.1, 56\%), Cellvbrio sp. BP (EIK45872.1, 48\%) and Reichenbachiella agariperforans (SHK69922.1, 44\%). The phylogenetic tree indicating the relationship between the ID2563 protein product with agarases from other microorganisms is shown in Fig. 1.

\section{Expression and purification of the agarase}

The sequence of the ID2563 gene with the wild-type signal peptide was amplified using the primers ID2563F/ID2563-R and cloned into a modified pProEX-HTa vector to produce recombinant agarase with an $\mathrm{N}$-terminal histiding tag. The recombinant protein was soluble and found in both the supernatant and cell extracts. Its activity in $1 \mathrm{~mL}$ of culture broth was $3.28 \mathrm{U}$ from the supernatant fraction and $1.17 \mathrm{U}$ in the cell extract fraction. The total activity, $4.99 \mathrm{U} / \mathrm{mL}$ of culture broth, was 8.6 times higher than that of Microbulbifer sp. Q7 (0.58 $\mathrm{U} / \mathrm{mL}$ ). Extracellular agarase was purified using a $\mathrm{Ni}$ Sepharose 6FF column and was approximately $65 \mathrm{kDa}$ 


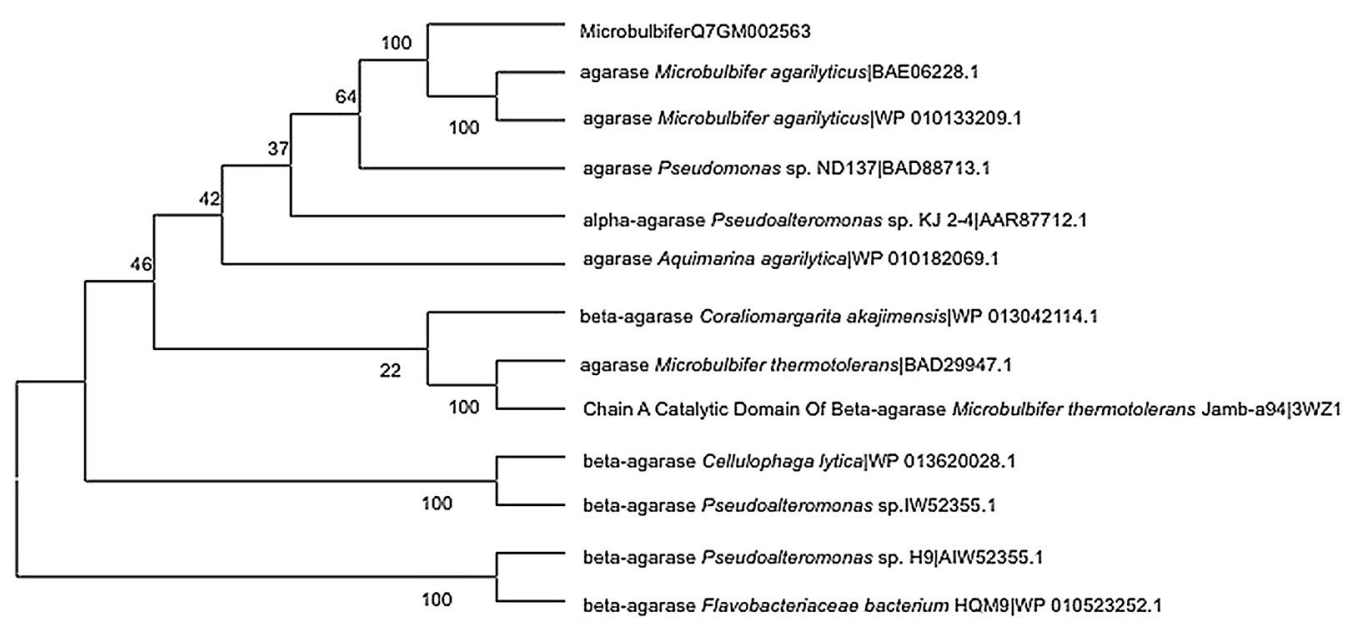

Fig. 1 The phylogenetic tree of the recombinant agarase

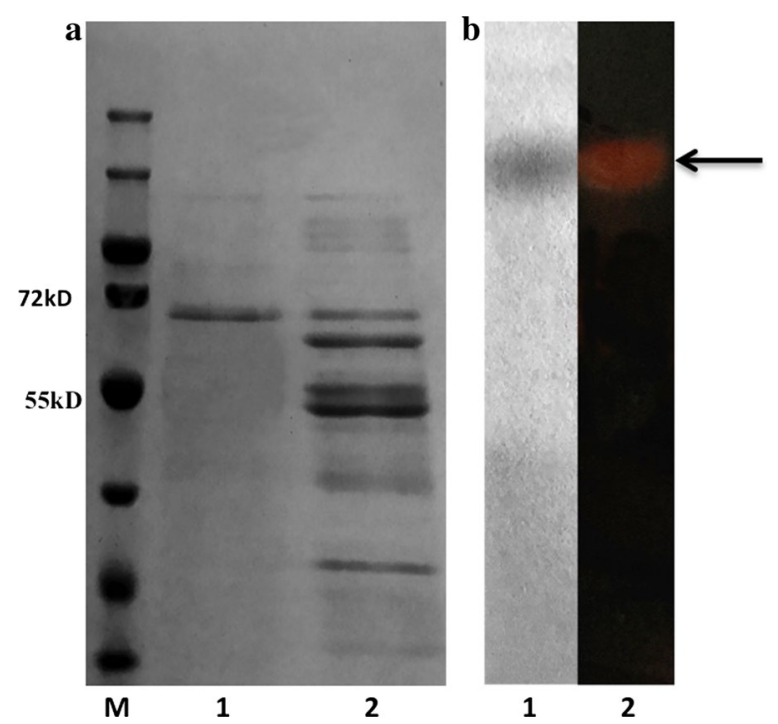

Fig. 2 SDS-PAGE and zymogram analysis of purified recombinant agarase. a SDS-PAGE analysis of the purified recombinant agarase. Lane M: protein markers. Lane 1: purified agarase. Lane 2: extracellular protein components. $\mathbf{b}$ Native-PAGE analysis of the purified agarase. Lane 1: purified agarase protein stained with Coomassie brilliant blue R-250. Lane 2: zymogram of the purified agarase. The native-PAGE gel was overlaid onto a sheet containing $2 \%(\mathrm{w} / \mathrm{v})$ agarose in Tris- $\mathrm{HCl}$ buffer ( $50 \mathrm{mM}, \mathrm{pH} 7.0$ ), incubated for $30 \mathrm{~min}$ at $40^{\circ} \mathrm{C}$, and then incubated with Lugol's iodine solution to visualize agarase activity

(Fig. 2a), consistent with the theoretical molecular mass. Zymogram analysis showed a single protein band with agarase activity.

\section{Enzymatic properties of the recombinant agarase}

The effect of temperature on activity was examined by measuring the relative activity at various temperatures ranging from 30 to $60{ }^{\circ} \mathrm{C}$. The highest activity was observed at $40{ }^{\circ} \mathrm{C}$ (Fig. 3a). Thermal stability experiments revealed agarase remained $90.12 \%$ of its activity at $37^{\circ} \mathrm{C}$ for $2 \mathrm{~h}$, greater than $55 \%$ activity at 40 and $42{ }^{\circ} \mathrm{C}$ for $1 \mathrm{~h}$, and $36.16 \%$ activity at $45^{\circ} \mathrm{C}$ for $1 \mathrm{~h}$ (Fig. 3b).

To study the effect of $\mathrm{pH}$, agarase activity was measured in several buffers at $40{ }^{\circ} \mathrm{C}$. Greater than $70 \%$ enzyme activity was observed for reactions between $\mathrm{pH} 4.0$ and 10.0 with the maximum activity observed at $\mathrm{pH}$ 6.0. Agarase was stable over a broad $\mathrm{pH}$ range, particularly in mildly alkaline conditions (Fig. 3c).

Several mental ions and other molecules were added to the standard reaction system to determine their effect on agarase activity. Activity was normalized to the standard condition in the absence of additives. The agarase activity was strongly inhibited by $\mathrm{Cu}^{2+}, \mathrm{Zn}^{2+}$ and $\mathrm{Fe}^{3+}$, whereas $5 \mathrm{mM} \mathrm{Na}^{+}$and $\mathrm{Fe}^{2+}$ slightly stimulated activity. Activity markedly increased in the presence of $0.5 \%$ $\beta$-mercaptoethanol (Table 1).

\section{Enzymatic product analysis}

Electrospray ionization mass spectrometry of the reaction product showed $\mathrm{m} / \mathrm{z}$ peaks at $629.19(\mathrm{M}-\mathrm{H})^{+}$, $665.17(\mathrm{M}+\mathrm{Cl})^{-}$and $675.20(\mathrm{M}+\mathrm{HCOO})^{-}$, corresponding to neoagarotetraose and $\mathrm{m} / \mathrm{z}$ peaks at 935.29 $(\mathrm{M}-\mathrm{H})^{-}, 971.27(\mathrm{M}+\mathrm{Cl})^{-}$and $981.29(\mathrm{M}+\mathrm{HCOO})^{-}$, corresponding to neoagarohexaose (Fig. 4). The anomeric carbon of agar-oligosaccharides and neoagar-oligosaccharides have different chemical shift. Therefore, the presence of anomer carbon by ${ }^{13} \mathrm{C}$-NMR could identify which oligosaccharides products resulted from the reaction. This information would further indicate the catalytic site of the agarase. The ${ }^{13} \mathrm{C}-\mathrm{NMR}$ spectrum of the reaction products did not indicate a signal at approximately $90 \mathrm{ppm}$ which was typically observed when 

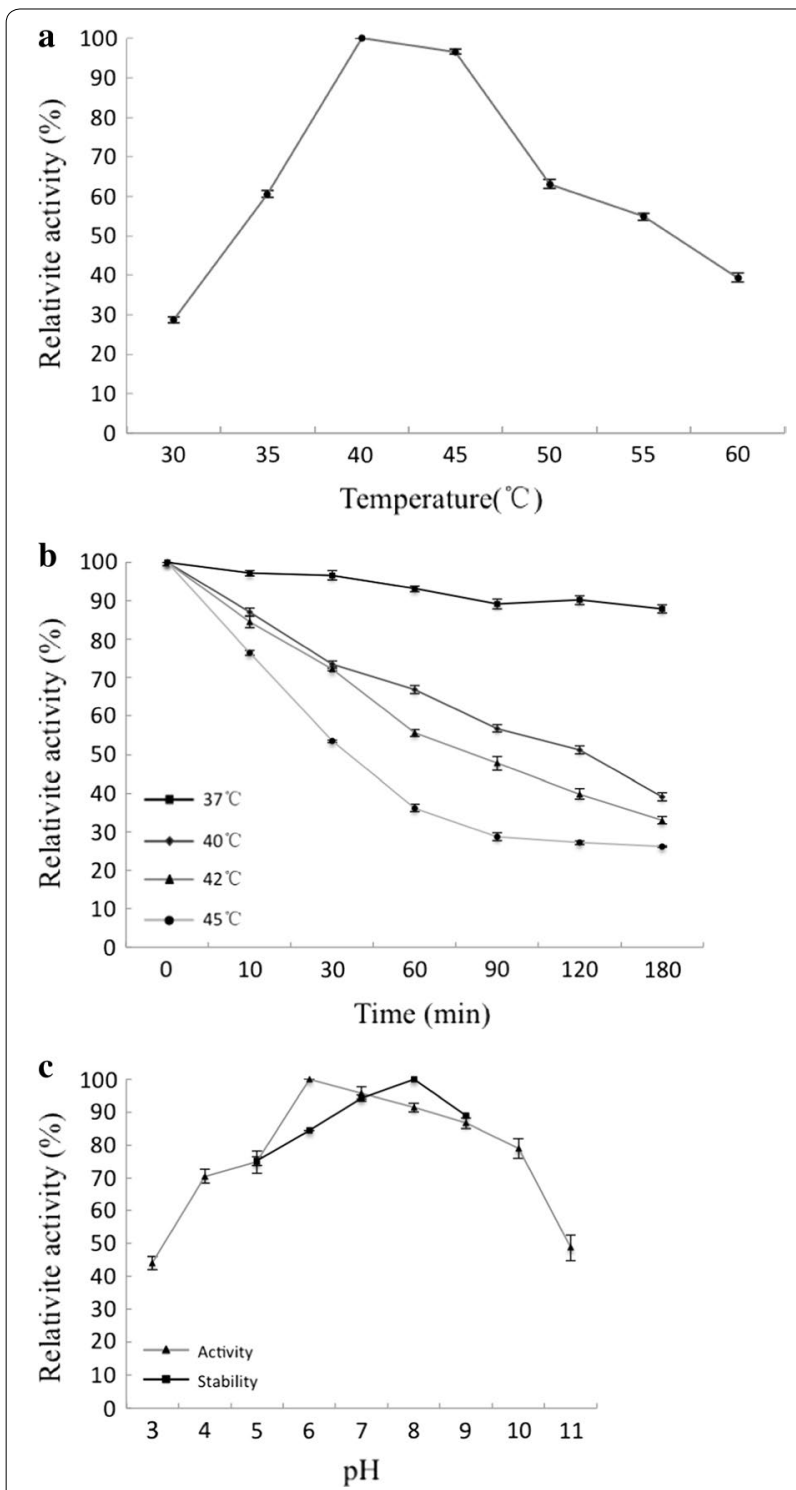

Fig. 3 Characterization of the recombinant agarase. a The effect of temperature on agarase activity. $\mathbf{b}$ Thermal stability of recombinant agarase. The agarase was pre-incubated at various temperatures, and remaining activity was measured at $42{ }^{\circ} \mathrm{C}$. c The optimal $\mathrm{pH}$ and $\mathrm{pH}$ stability of agarase was measured in $50 \mathrm{mM} \mathrm{Na}_{2} \mathrm{HPO}_{4}$-citric acid ( $\mathrm{pH}$ 3.0, 4.0 and 5.0), $50 \mathrm{mM}$ sodium phosphate ( $\mathrm{pH} 6.0,7.0$ and 8.0), $50 \mathrm{mM}$ Tris- $\mathrm{HCl}(\mathrm{pH} 9.0)$ and $50 \mathrm{mM} \mathrm{Na}_{2} \mathrm{CO}_{3}-\mathrm{NaOH}(\mathrm{pH} 10.0$ and 11.0)

$\alpha-(1,3)$ linkages are hydrolyzed to form agaro-oligosaccharides (Lahaye et al. 1989). The main resonance signals of anomeric carbons were in accordance with neoagaro-oligosaccharides, In Fig. 5, signals at approximately 96 and $92 \mathrm{ppm}$ were assigned to the $\alpha$ - and $\beta$-anomeric carbons in the reducing end of the 3-O-linked $\beta$-Dgalactopyranose residue, respectively. Multiple signals were observed for the $\alpha / \beta$-anomeric carbons of the 3-O-linked $\beta$-D-galactopyranose indicating that the
Table 1 Effects of ions and chemical reagents on agarase activity

\begin{tabular}{llr}
\hline Ions and chemical reagents & Concentrations & Relative activity (\%) \\
\hline $\mathrm{Na}^{+}$ & $5 \mathrm{mM}$ & $113.34 \pm 0.57$ \\
& $20 \mathrm{mM}$ & $97.93 \pm 1.02$ \\
& $50 \mathrm{mM}$ & $96.94 \pm 0.75$ \\
& $5 \mathrm{mM}$ & $116.46 \pm 0.43$ \\
$\mathrm{Fe}^{2+}$ & $20 \mathrm{mM}$ & $82.75 \pm 0.73$ \\
& $50 \mathrm{mM}$ & $77.65 \pm 0.82$ \\
$\mathrm{Cu}^{2+}$ & $5 \mathrm{mM}$ & $6.2 \pm 0.45$ \\
$\mathrm{~K}^{+}$ & $5 \mathrm{mM}$ & $97.26 \pm 0.63$ \\
$\mathrm{Ca}^{2+}$ & $5 \mathrm{mM}$ & $96.78 \pm 0.34$ \\
$\mathrm{Zn}^{2+}$ & $5 \mathrm{mM}$ & $14.97 \pm 1.02$ \\
$\mathrm{Mg}^{2+}$ & $5 \mathrm{mM}$ & $76.92 \pm 0.36$ \\
$\mathrm{Li}^{+}$ & $5 \mathrm{mM}$ & $92.00 \pm 0.58$ \\
Fe & $3 \mathrm{mM}$ & $34.65 \pm 1.09$ \\
EDTA & $5 \mathrm{mM}$ & $86.47 \pm 1.44$ \\
$\mathrm{SDS}$ & $5 \mathrm{mM}$ & $99.26 \pm 0.78$ \\
DTT & $5 \mathrm{mM}$ & $103.44 \pm 0.99$ \\
Urea & $5 \mathrm{mM}$ & $96.01 \pm 0.73$ \\
Tween-80 & $0.5 \%(\mathrm{v} / \mathrm{v})$ & $89.72 \pm 0.82$ \\
Triton-100 & $0.5 \%(\mathrm{v} / \mathrm{v})$ & $100.94 \pm 0.69$ \\
$\beta-M e r c a p t o e t h a n o l$ & $0.5 \%(\mathrm{v} / \mathrm{v})$ & $141.05 \pm 0.74$ \\
\hline
\end{tabular}

The data shown are representative of three independent experiments The activity measured under the standard condition is defined as $100 \%$ The concentration indicates the final reagents concentrations in the reaction

reaction products consisted of several neoagaro-oligosaccharides with different degrees of polymerization. These data suggest the hydrolytic products were neoagarotetraose and neoagarohexaose, and that the recombinant agarase is a $\beta$-agarase.

To determine the hydrolytic pattern of the recombinant agarase, a time course of its activity was carried out by TLC. The agarase initially produced agarose-oligosaccharides of various lengths, which were progressively converted into smaller oligomers. Mass spectrometry analyses of the agarose-oligosaccharide spots extracted from the TLC plate indicated that the final reaction products are neoagarotetraose (Fig. 6b) and neoagarohexaose (Fig. 6c). These results confirm the recombinant agarase is an endo-type- $\beta$-agarase that produces neoagarotetraose and neoagarohexaose.

\section{Discussion}

Microbulbifer sp. Q7 was isolated from the gut of sea cucumber. According to the results of genomic analysis, seven agarase-encoding sequences and five alginate lyaseencoding sequences were found (Yang et al. 2017). A few studies have shown that Microbulbifer plays a critical role in carbon recycling from marine biomass by degrading 


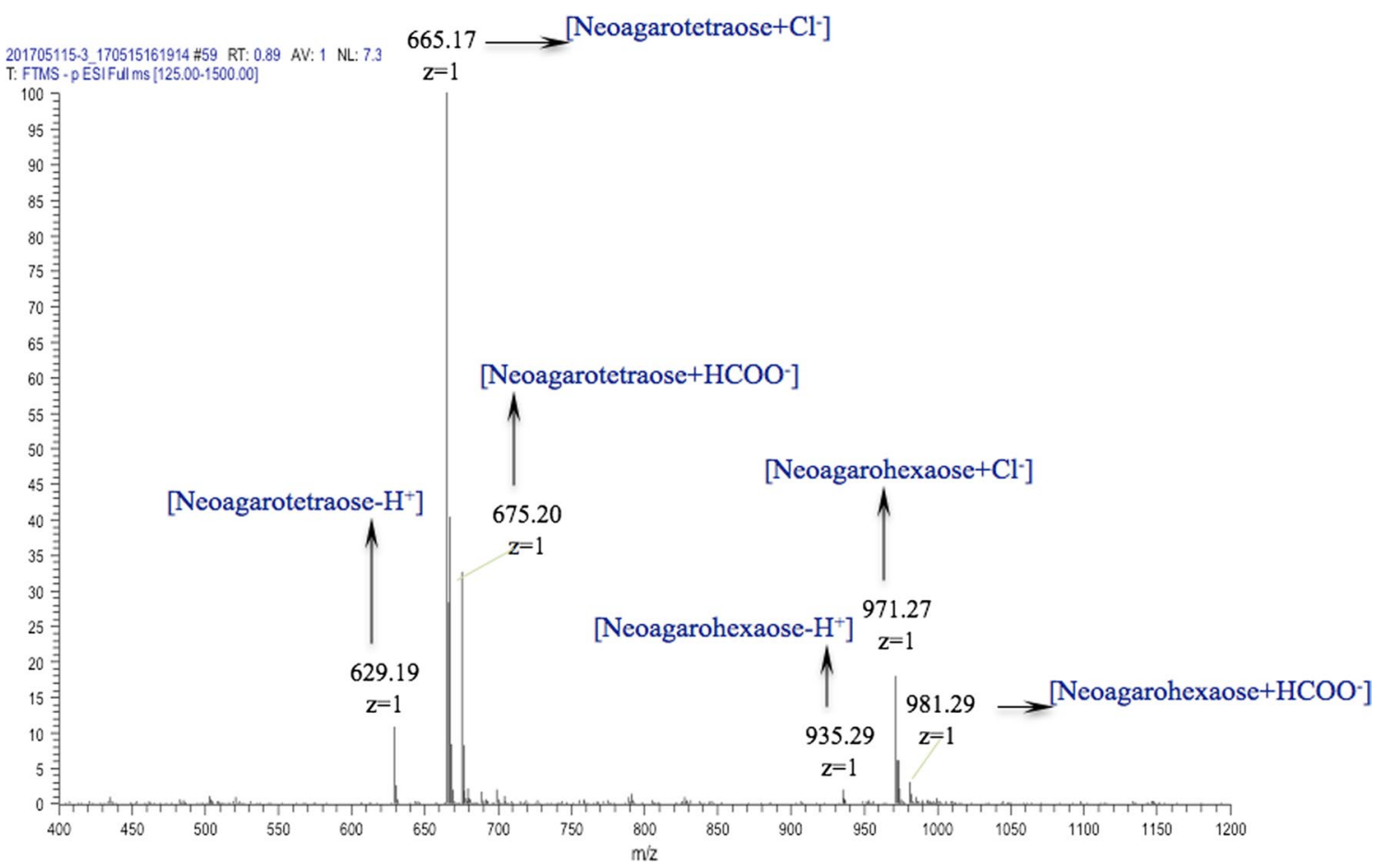

Fig. 4 Determination of molecular masses of the hydrolytic products by mass spectrometry

CARBON 01

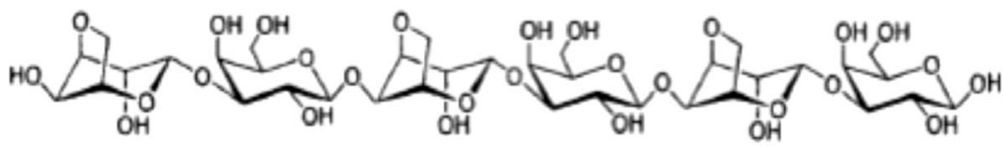

Anr

Gnr

A

G

Ar

$\mathrm{Gr}$

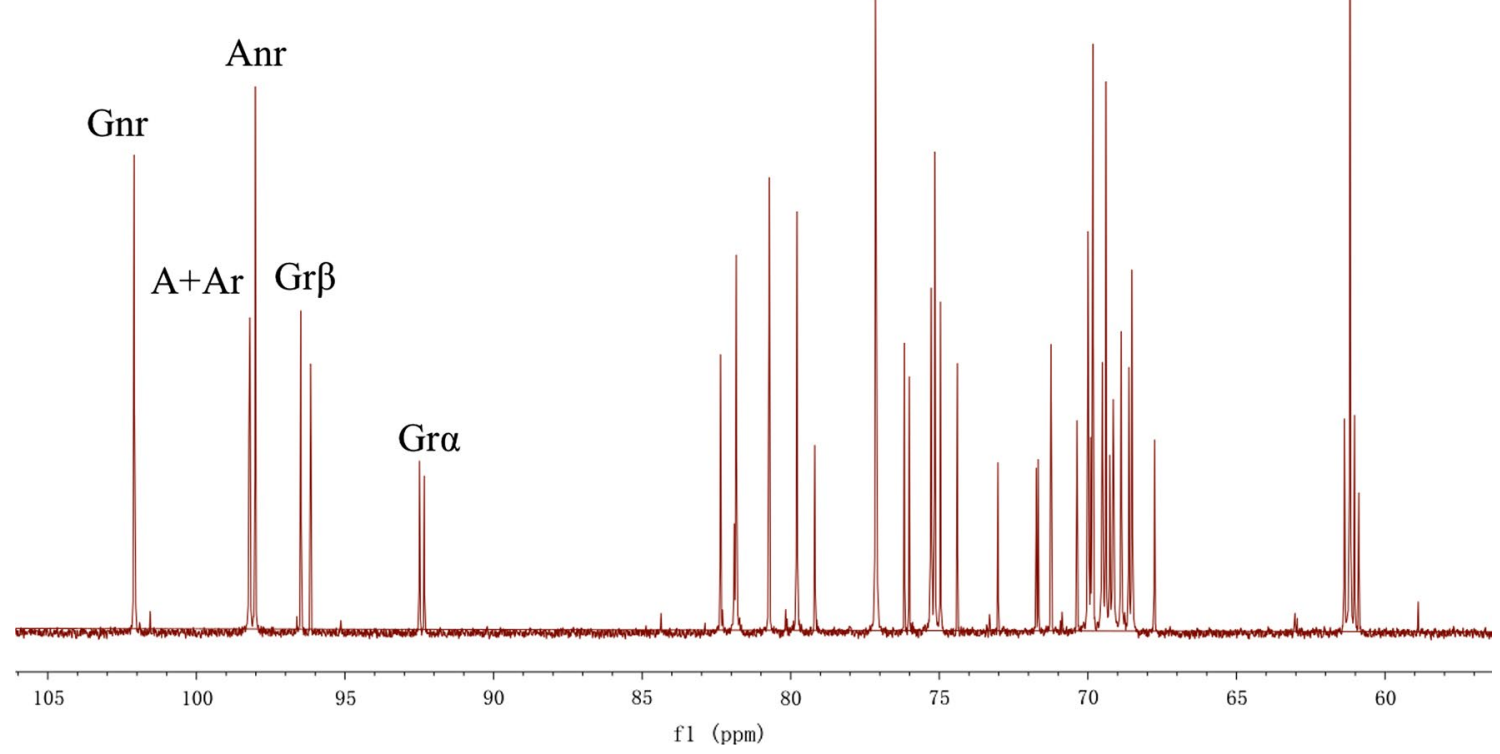

Fig. $5{ }^{13} \mathrm{C}-\mathrm{NMR}$ spectrum of the reaction products of the agarase. The upper formula is the structure of neoagarohexaose. Peak assignments are labeled according to the nomenclature defined in the upper formula. A and $\mathrm{G}$ refer to the 4-O-linked 3,6-anhydro- $\alpha$-L-galactopyranose and 3-O-linked $\beta$-D-galactopyranose; $r$ and $n r$ denote the reducing and non-reducing end; $\alpha / \beta$ for anomer 


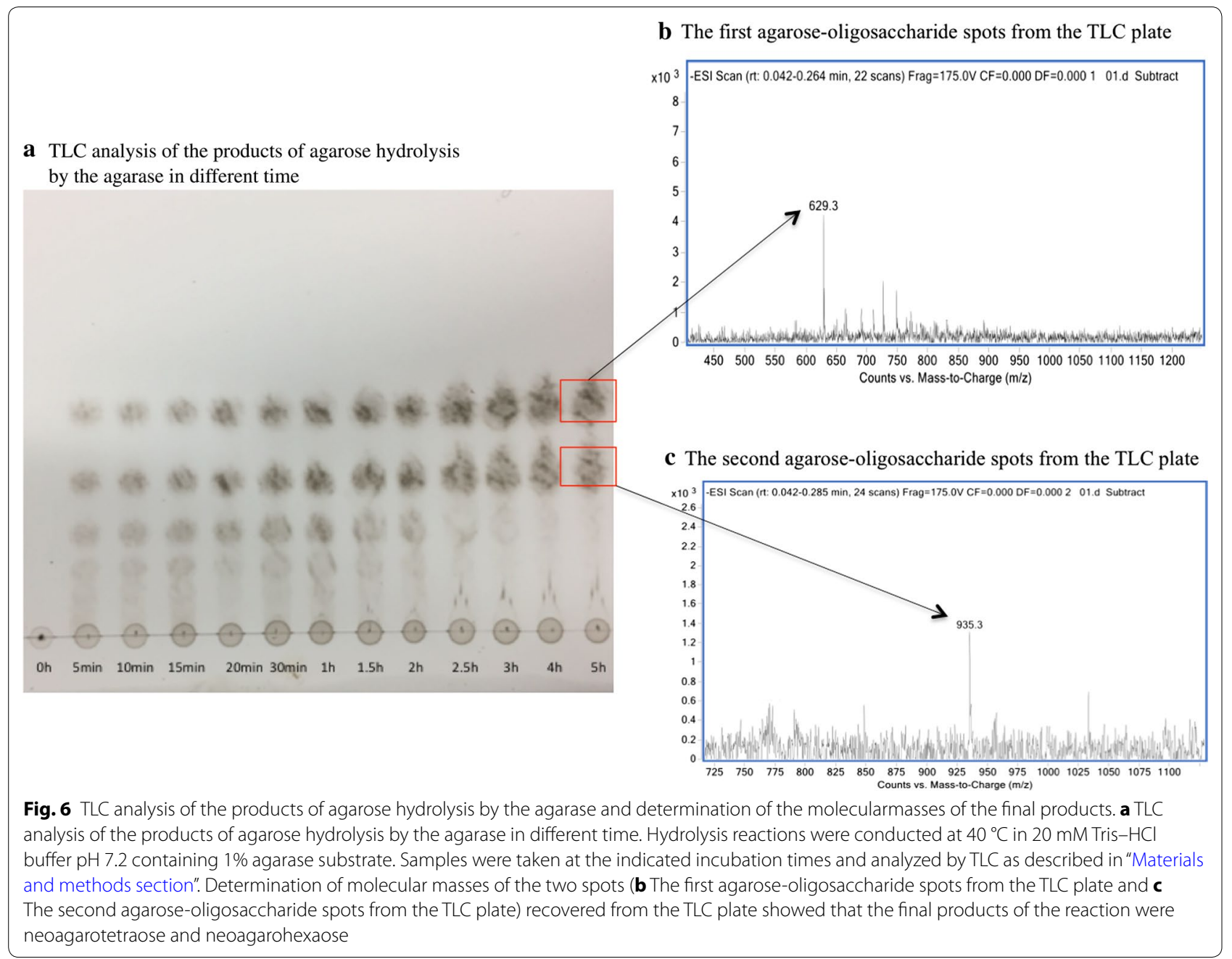

complex polysaccharides such as agar, carrageenan and alginate (Weiner et al. 2008). Microbulbifer has been isolated from rotten brown alga (Zhu et al. 2016), seawater (Sun et al. 2014) and mangrove forests (Mai et al. 2016; Moh et al. 2017). However, the seaweed-degrading strain of Microbulbifer isolated from the sea cucumber gut has not been previously reported. This study shows that the gut of sea cucumber is a source of seaweed polysaccharide degrading bacteria. Meanwhile, there were few reports on the agarase-encoding gene from Microbulbifer (Ohta et al. 2004). In our studies ID2563 has the highest homology with other agarases in the NCBI database among the seven agarase-encoding genes founded from Microbulbifer sp. Q7 genome. Protein BLAST results showed that the agarase encoded by ID2563 was novel, and had the highest sequence identity of $85 \%$ with the agarase from M. agarilyticus (BAE06228.1).

Soluble recombinant protein was successfully expressed in E. coli. Agarase found in both the intracellular and extracellular fractions were active. The total enzyme activity was $4.99 \mathrm{U} / \mathrm{mL}$ in fermentation medium, $65.73 \%$ of which was found in the agarase from the extracellular fraction under the action of the wild-type signal peptide. The signal peptide was composed of 19 , mostly hydrophobic, amino acids $\left(\mathrm{M}_{1}-\mathrm{K}_{2}-\mathrm{T}_{3}-\mathrm{T}_{4}-\mathrm{Q}_{5}-\mathrm{G}_{6}-\mathrm{A}_{7}-\mathrm{L}_{8}-\mathrm{A}_{9}-\mathrm{A}_{10^{-}}\right.$ $\left.\mathrm{L}_{11}-\mathrm{V}_{12}-\mathrm{F}_{13}-\mathrm{S}_{14}-\mathrm{T}_{15}-\mathrm{P}_{16}-\mathrm{L}_{17}-\mathrm{M}_{18}-\mathrm{A}_{19}\right)$. The previous study has showed the wild-type signal sequence can play an effective role on the secretion of recombinant protein in $E$. coli (Liu et al. 2014). However, the wild-type signal peptide is generally removed (Kim et al. 2010) or substituted with a secretion signal peptide (Kaewthai et al. 2010) before inserting the gene into the expression vector to facilitate overexpression. There is no general rule for selecting a proper signal sequence for recombinant proteins that will guarantee its secretion (Choi and Lee 2004). In this study, the wild-type signal peptide was retained and the recombinant agarase was successfully secreted by the $E$. coli. Thus, the wild-type signal peptide 
sequence from Microbulbifer may be useful for constructing secretory expression vectors.

Similar to most of the GH16 $\beta$-agarases (Aoki et al. 1990; Jung et al. 2017; Lin et al. 2017), the optimal temperature for extracellular agarase was around $40{ }^{\circ} \mathrm{C}$. Its optimal $\mathrm{pH}$ was 6.0 , which was slightly acidic in comparison with most of the previously reported $\beta$-agarases. The $\mathrm{pH}$ stability of agarase and its tolerance to high concentrations of ions and other chemical regents are important factors for its use in industrial applications. The agarase was stable between $\mathrm{pH} 6.0$ and 9.0, which was a much wider range than most of the previously reported agarases, including those from Alteromonas sp. E-1 (Kirimura et al. 1999), Vibrio sp. AP-2 (Aoki et al. 1990), Thalassospira profundimonas fst-13007 (Zeng et al. 2016), Gayadomonas joobiniege G7 (Jung et al. 2017) and Aquimarina agarilytica ZC1 (Lin et al. 2017). These characteristics greatly improve the application potential of this agarase. The agarase was highly inhibited by $\mathrm{Cu}^{2+}, \mathrm{Zn}^{2+}$ and $\mathrm{Fe}^{3+}$. However, $5 \mathrm{mM} \mathrm{Na}^{+}$and $\mathrm{Fe}^{2+}$ slightly improved its activity. Moreover, agarase activity was enhanced by $41 \%$ in the presence of $\beta$-mercaptoethanol, suggesting the catalytic site may contain thiols (Fu et al. 2008).

Sequence analysis indicated that the agarase belongs to the GH16 family. Thin layer chromatography, mass spectrometry and ${ }^{13} \mathrm{C}-\mathrm{NMR}$ analysis of the hydrolytic products further confirmed the conclusion. The final products of the recombinant agarase were neoagarotetraose and neoagarohexaose, a characteristic of the GH16 family agarases such as the agarase from Zobellia galactanivorans Dsij (Allouch et al. 2003), Agarivorans sp. LQ48 (Long et al. 2010) and Flammeovirga sp. SJP92 (Dong et al. 2016). The final products were concentrated in the supernatant of the maximum precipitation, which accounts for $90.47 \%$ of the total degradation products. Mass spectrometry analyses indicated the final products were primarily composed of neoagarotetraose and neoagarohexaose. Previous studies have suggested that the neoagarotetraose has many biological functions, such as anti-oxidative properties (Wu et al. 2010), whitening effects (Jang et al. 2009) and prebiotic properties ( Hu et al. 2006). Thus, the recombinant agarase provides an efficient tool to produce the functional neoagar-oligosaccharides with potential applications in the cosmetic, food and pharmaceutical industries.

\section{Abbreviations \\ E. coli: Escherichia coli; DNS: 3,5-dinitrosalicylic acid; SDS-PAGE: sodium dodecyl sulfate polyacrylamide gel electrophoresis; ESI-MS: electrospray ionization mass spectrometry; ${ }^{13} \mathrm{C}-\mathrm{NMR}$ : carbon-13 nuclear magnetic resonance; TLC: thin layer chromatography.}

\section{Authors' contributions}

HM and LL conceived and designed the study. QS performed the experiments, sorted data and written the manuscript. TJ, YY and MY assisted in the experiment and collected data. All authors read and approved the final manuscript.

\section{Acknowledgements}

This work was supported by Shandong Province Project of Science and Technology (2014GHY115037). We want to show our gratitude to the funding.

\section{Competing interests}

I confirm that I have read SpringerOpen's guidance on competing interests and have included a statement indicating that none of the authors have any competing interests in the manuscript.

\section{Availability of data and materials}

The data and material in this manuscript are available.

\section{Consent for publication}

All authors agree with this article published.

\section{Ethics approval and consent to participate}

This article does not contain any studies with human participants or animals performed by any of the authors.

Funding

Shandong Province Project of Science and Technology (2014GHY115037).

\section{Publisher's Note}

Springer Nature remains neutral with regard to jurisdictional claims in published maps and institutional affiliations.

Received: 4 December 2017 Accepted: 12 December 2017

Published online: 19 December 2017

\section{References}

Allouch J, Jam M, Helbert W, Barbeyron T, Kloareg B, Henrissat B, Czjzek M (2003) The three-dimensional structures of two beta-agarases. J Biol Chem 278:47171-47180

Aoki T, Araki T, Kitamikado M (1990) Purification and characterization of a novel $\beta$-agarase from Vibrio sp. AP-2. FEBS J 187:461-465. https://doi. org/10.1111/j.1432-1033.1990.tb15326.x

Choi JH, Lee SY (2004) Secretory and extracellular production of recombinant proteins using Escherichia coli. Appl Microbiol Biotechnol 64:625-635

Dong Q, Ruan L, Shi H (2016) A $\beta$-agarase with high pH stability from Flammeovirga sp. S.JP92. Carbohydr Res 432:1-8

Duckworth M, Yaphe W (1971) The structure of agar: part I. Fractionation of a complex mixture of polysaccharides. Carbohydr Res 16:189-197

Fu XT, Lin H, Kim SM (2008) Purification and characterization of a novel B-agarase, AgaA34, from Agarivorans albus, YKW-34. Appl Microbiol Biotechnol 78:265-273

Giordano A, Andreotti G, Tramice A, Trincone A (2006) Marine glycosyl hydrolases in the hydrolysis and synthesis of oligosaccharides. J Biotechnol 1:511-530

Hu B, Gong Q, Wang Y, Ma YM, Li JB, Yu WG (2006) Prebiotic effects of neoagaro-oligosaccharides prepared by enzymatic hydrolysis of agarose. Anaerobe 12:260-266

Jang MK, Lee DG, Kim NY, Yu KH, Jang HJ, Lee SW, Jang HJ, Lee YJ, Lee SH (2009) Purification and characterization of neoagarotetraose from hydrolyzed agar. J Microbiol Biotechnol 19:1197-1200

Jung S, Jeong B, Hong S, Lee C (2017) Cloning, expression, and biochemical characterization of a novel acidic GH16 $\beta$-Agarase, AgaJ11, from Gayadomonas joobiniege G7. Appl Biochem Biotechnol 181:961-971

Kaewthai N, Harvey AJ, Hrmova M, Brumer H, Ezcurra I, Teeri TT, Fincher GB (2010) Heterologous expression of diverse barley XTH genes in the yeast Pichia pastoris. Plant Biotechnol 27:251-258

Kim HT, Lee S, Lee D, Kim HS, Bang WG, Kim KH, Choi IG (2010) Overexpression and molecular characterization of Aga50D from Saccharophagus degradans 2-40: an exo-type $\beta$-agarase producing neoagarobiose. Appl Microbiol Biotechnol 86:227-234

Kirimura K, Masuda N, Iwasaki Y, Nakagawa H, Kobayashi R, Usami S (1999) Purification and characterization of a novel $\beta$-agarase from an alkalophilic bacterium, Alteromonas sp. E-1. J Biosci Bioeng 87:436-441 
Kobayashi R, Takisada M, Suzuki T, Kohtaro K, Usami S (1997) Neoagarobiose as a novel moisturizer with whitening effect. Biosci Biotechnol Biochem 61:162-163

Lahaye M, Yaphe W, Viet MTP, Rochas C (1989) C-NMR spectroscopic investigation of methylated and charged agarose oligosaccharides and polysaccharides. Carbohydr Res 190:249-265

Lin B, Liu Y, Lu G, Zhao M, Hu Z (2017) An agarase of glycoside hydrolase family 16 from marine bacterium Aquimarina agarilytica ZC1. FEMS Microbiol Lett 364(4):fnx012. https://doi.org/10.1093/femsle/fnx012

Liu Z, Tian L, Chen Y, Mou H (2014) Efficient extracellular production of K-carrageenase in Escherichia coli: effects of wild-type signal sequence and process conditions on extracellular secretion. J Biotechnol 185:8-14

Long M, Yu Z, Xu X (2010) A novel beta-agarase with high pH stability from marine Agarivorans sp. LQ48. Mar Biotechnol 12:62-69

Mai Z, Su H, Zhang S (2016) Isolation and characterization of a glycosyl hydrolase family $16 \beta$-agarase from a mangrove soil metagenomic library. Int J Mol Sci 17(8):1360. https://doi.org/10.3390/ijms17081360

Miller G (1959) Use of dinitrosalicylic acid reagent for determination of reduc ing sugar. Anal Chem 31:426-428

Minegishi H, Shimane Y, Echigo A, Ohta Y, Hatada Y, Kamekura M, Maruyama T, Usami R (2013) Thermophilic and halophilic $\beta$-agarase from a halophilic archaeon Halococcus sp. 197A. Extremophiles 17:931-939

Moh TH, Lau NS, Furusawa G, Amirul A (2017) Complete genome sequence of Microbulbifer sp. CCB-MM1, a halophile isolated from Matang Mangrove Forest, Malaysia. Stand Genom Sci 12:36. https://doi.org/10.1186/ s40793-017-0248-0

Ohta Y, Nogi Y, Miyazaki M, Li ZJ, Hatada Y, Ito S, Horikoshi K (2004) Enzymatic properties and nucleotide and amino acid sequences of a thermostable beta-agarase from the novel marine isolate, jamb-a94. Biosci Biotechnol Biochem 68:1073-1081

Potin P, Richard C, Rochas C, Kloareg B (1993) Purification and characterization of the a-agarase from Alteromonas agarlyticus (Cataldi) comb. nov., strain GJ1B. FEBS J 214:599-607. https://doi.org/10.1111/j.1432-1033.1993. tb17959.x
Sun C, Chen Y, Zhang X, Pan J, Cheng H, Wu M (2014) Draft genome sequence of Microbulbifer elongatus strain HZ11, a brown seaweed-degrading bacterium with potential ability to produce bioethanol from alginate. Mar Genom 18:83-85

Suzuki H, Sawai Y, Suzuki T, Kawai K (2003) Purification and characterization of an extracellular beta-agarase from Bacillus sp. MK03. J Biosci Bioeng 95:328-334

Wang J, Jiang X, Mou H, Guan H (2004) Anti-oxidation of agar oligosaccharides produced by agarase from a marine bacterium. J Appl Phycol 16:333-340

Weiner RM, Taylor LE 2nd, Henrissat B, Hauser L, Land M, Coutinho PM, Rancurel C, Saunders EH, Longmire AG, Zhang H, Bayer EA, Gilbert HJ, Larimer F, Zhulin IB, Ekborg NA, Lamed R, Richardson PM, Borovok I, Hutcheson $S$ (2008) Complete genome sequence of the complex carbohydratedegrading marine bacterium, Saccharophagus degradans strain 2-40T. PLOS Genet 4(5):e1000087

Wu SC, Wen TN, Pan CL (2010) Algal-oligosaccharide-lysates prepared by two bacterial agarases stepwise hydrolyzed and their anti-oxidative properties. Fish Sci 71:1149-1159

Yang M, Yu Y, Jin TY, Mou HJ, Li L (2017) Genomic analysis of Microbulbifer sp. Q7 exhibiting degradation activity toward seaweed polysaccharides. Mar Genom. https://doi.org/10.1016/j.margen.2017.07.003

Yun EJ, Lee S, Ji HK, Bo BK, Hee TK, Sun HL, Jeffrey GP, Nam JK, In-Geol C, Kyoung HK (2013) Enzymatic production of 3,6-anhydro-L-galactose from agarose and its purification and in vitro skin whitening and anti-inflammatory activities. Appl Microbiol Biotechnol 97:2961-2970

Zeng C, Zhang L, Miao S, Zhang Y, Zeng S, Zheng B (2016) Preliminary characterization of a novel $\beta$-agarase from Thalassospira profundimonas. Springerplus 5:1-8

Zhu Y, Wu L, Chen Y, Ni H, Xiao A, Cai H (2016) Characterization of an extracellular biofunctional alginate lyase from marine Microbulbifer sp. ALW1 and antioxidant activity of enzymatic hydrolysates. Microbiol Res 182:49-58

\section{Submit your manuscript to a SpringerOpen ${ }^{\odot}$ journal and benefit from:}

- Convenient online submission

- Rigorous peer review

- Open access: articles freely available online

- High visibility within the field

- Retaining the copyright to your article

Submit your next manuscript at $>$ springeropen.com 